\title{
PARP inhibitors protect against sex- and AAG-dependent alkylation-induced neural degeneration
}

\author{
Mariacarmela Allocca ${ }^{1,3}$, Joshua J. Corrigann ${ }^{1,3}$, Kimberly R. Fake ${ }^{1,3}$, Jennifer A. \\ Calvo $^{1,3}$ and Leona D. Samson ${ }^{1,2,3,4}$ \\ ${ }^{1}$ Department of Biological Engineering, Massachusetts Institute of Technology, Cambridge, MA 02139, USA \\ ${ }^{2}$ Department of Biology, Massachusetts Institute of Technology, Cambridge, MA 02139, USA \\ ${ }^{3}$ Center for Environmental Health Sciences, Massachusetts Institute of Technology, Cambridge, MA 02139, USA \\ ${ }^{4}$ David H. Koch Institute for Integrative Cancer Research, Massachusetts Institute of Technology, Cambridge, MA 02139, USA \\ Correspondence to: Leona D. Samson, email: Isamson@mit.edu \\ Keywords: alkylating agents, PARPI, PARP inhibitors, AAG/MPG, retinal and cerebellar degeneration \\ Received: April 19, $2017 \quad$ Accepted: June 08, $2017 \quad$ Published: August 03, 2017 \\ Copyright: Allocca et al. This is an open-access article distributed under the terms of the Creative Commons Attribution License \\ 3.0 (CC BY 3.0), which permits unrestricted use, distribution, and reproduction in any medium, provided the original author and \\ source are credited.
}

\section{ABSTRACT}

Alkylating agents are commonly used to treat cancer. Although base excision repair (BER) is a major pathway for repairing DNA alkylation damage, under certain conditions, the initiation of BER produces toxic repair intermediates that damage healthy tissues. The initiation of BER by the alkyladenine DNA glycosylase (AAG, a.k.a. MPG) can mediate alkylation-induced cytotoxicity in specific cells in the retina and cerebellum of male mice. Cytotoxicity in both wild-type and Aag-transgenic (AagTg) mice is abrogated in the absence of Poly(ADP-ribose) polymerase-1 (PARP1). Here, we tested whether PARP inhibitors can also prevent alkylation-induced retinal and cerebellar degeneration in male and female WT and AagTg mice. Importantly, we found that WT mice display sex-dependent alkylation-induced retinal damage (but not cerebellar damage), with WT males being more sensitive than females. Accordingly, estradiol treatment protects males against alkylation-induced retinal degeneration. In AagTg male and female mice, the alkylation-induced tissue damage in both the retina and cerebellum is exacerbated and the sex difference in the retina is abolished. PARP inhibitors, much like Parp1 gene deletion, protect against alkylation-induced AAG-dependent neuronal degeneration in WT and AagTg mice, regardless of the gender, but their efficacy in preventing alkylation-induced neuronal degeneration depends on PARP inhibitor characteristics and doses. The recent surge in the use of PARP inhibitors in combination with cancer chemotherapeutic alkylating agents might represent a powerful tool for obtaining increased therapeutic efficacy while avoiding the collateral effects of alkylating agents in healthy tissues.

\section{INTRODUCTION}

DNA damage is continually induced by environmental agents and chemically reactive byproducts of normal cellular metabolism. Moreover, DNA damage is often deliberately induced during the course of cancer chemotherapy. One class of commonly-utilized chemotherapy agents is alkylating agents, a broad group of compounds that add alkyl groups to DNA. Alkylating agents generate numerous types of alkylated DNA base lesions, including $O^{6}$-methylguanine $\left(O^{6} \mathrm{meG}\right), 7$-methylguanine $(7 \mathrm{meG})$ and 3-methyladenine (3meA). The effectiveness of alkylators as cancer chemotherapeutic agents relies on the induction of cell death in rapidly dividing tumor cells by toxic DNA lesions that interfere with DNA replication and RNA transcription. DNA repair pathways have evolved to cope 
with recurring DNA damage and, for the most part, provide protection in healthy tissues. The base excision repair (BER) pathway repairs a variety of alkylated DNA bases [1,2], and the AAG DNA glycosylase (a.k.a. MPG) initiates BER by recognizing and excising $7 \mathrm{meG}$ and $3 \mathrm{meA}$. Following base excision, an apurinic/apyrimidinic endonuclease (APE1) hydrolyzes the phosphodiester backbone at the abasic site, generating a single-stranded DNA break (SSB) with 3'OH and 5'deoxyribose-5-phosphate (5'dRP) termini. DNA polymerase $\beta(\mathrm{Pol} \beta)$ removes the 5 'dRP terminus and conducts single-nucleotide gap filling synthesis. BER is completed upon ligation of the nicked DNA by DNA Ligase I or the Xrcc1/Ligase III $\alpha$ complex. Poly(ADP-ribose) polymerase 1 (PARP1, a.k.a. ADP-Ribosyltransferase1/ ADPRT1 or ADP-Ribosyltransferase Diphtheria Toxin-Like 1/ARTD1) is a multi-functional protein that mediates several cellular processes and plays an important role in BER [312]. PARP1 acts as a SSB sensor, and, upon binding a SSB containing a 5 'dRP terminus, is activated to use $\mathrm{NAD}^{+}$to catalyze the addition of long branched polymers of ADPribose (PAR) to several nuclear proteins, including itself, DNA polymerases, DNA ligases, transcription factors and histones [9, 13, 14]. PARylation of histones, PARP1, and chromatin remodeling enzymes serves to relax chromatin, allowing DNA repair proteins access to DNA damage [15-17]. Moreover, PARP1 auto-modification is thought to recruit XRCC1, the BER scaffold protein that facilitates the formation of a complex of BER enzymes, including Pol $\beta$ and DNA Ligase III [18-20]. With the completion of repair, PARP1 dissociates from the DNA and PAR is rapidly cleaved, primarily by PAR glycohydrolase [21]. Taken together, these aspects of PARP1's function serve to facilitate BER, allowing cells to recover from DNA damage.

Although BER can efficiently repair DNA alkylation damage in most cells, in certain cell types, the initiation of BER can generate toxic repair intermediates that cause damage to healthy tissues. Both SSBs and AP sites exert their toxicity as a function of blocking transcription and replication [22] and by generating mutations via translesion DNA synthesis [23-26]. Further, large numbers of SSBs can indirectly induce toxicity through hyperactivation of PARP1. Indeed, PARP1 can act as a cell death mediator $[27,28]$; upon excessive DNA damage, PARP1 hyperactivation vastly increases $\mathrm{NAD}^{+}$ consumption, resulting in depletion of both $\mathrm{NAD}^{+}$and ATP, such that cells succumb to bioenergetic failure and necrotic cell death $[27,29,30]$. Independent of $\mathrm{NAD}^{+} /$ ATP depletion, the PAR polymer inhibits the hexokinase 1 , resulting in the block of glycolysis with consequent energy collapse and cell death [31]. The PAR polymer can also promote cell death by facilitating translocation of the apoptosis inducing factor (AIF) from mitochondria to the nucleus, resulting in chromatin condensation, caspaseindependent DNA degradation, and ultimately cell death [32-34]. Therefore, although BER is essential for the repair of many different types of DNA damage, it must be carefully regulated to avoid any imbalance and consequent accumulation of toxic BER intermediates.

Recently, using mouse genetic models, we demonstrated the importance of both AAG and PARP1 in modulating in vivo alkylation toxicity in healthy tissues. The alkylating agent, methyl methanesulfonate (MMS), induces tissue damage in a specific subset of tissues, including retina and cerebellum $[35,36]$, in WT male mice. Modest increases in AAG activity in a transgenic mouse model (AagTg mice) increase (rather than decrease) susceptibility to the alkylating agent for both whole-animal survival and for tissue damage $[35,36]$. In the absence of AAG activity, these tissues are remarkably refractory to MMS-induced cell death. The AAG-mediated alkylation sensitivity in the retina and cerebellum, for both wild-type (WT) and AagTg mice, is entirely PARP1-dependent, being wholly prevented in the absence of PARP1 resulting from a null mutation in the Parpl gene.

Several PARP inhibitors have been developed, with some in advanced clinical trials for the treatment of various tumors, either alone or in combination with other chemotherapeutics $[37,38]$. These include Veliparib and Olaparib, whose structures contain a nicotinamide moiety that competes with $\mathrm{NAD}^{+}$for PARP binding, making them efficient catalytic inhibitors of PARP. In addition to catalytic inhibition, the potency of PARP inhibitors also depends on their DNA trapping ability [39]. It turns out that PARP inhibitors can trap PARP1 on DNA, forming complexes that interfere with replication and transcription [39-45]. In the presence of PARP inhibitors, PARP1 still binds to SSBs, but auto-PARylation is prevented; inhibited PARP1 thus becomes trapped on the BER intermediates. The trapped/inhibited PARP1 complex eventually leads to stalled replication forks, accumulation of double-strand breaks (DSB) and cell death. Hence, PARP inhibitors can have opposite effects: (i) promote cell death by diminishing BER or by trapping PARP1 on DNA, leading to the induction of DSBs; (ii) prevent cell death by avoiding PARP1 hyperactivation and NAD ${ }^{+} / \mathrm{ATP}$ depletion.

Here, we tested whether the MMS-induced neuronal degeneration in WT and AagTg mice would be inhibited or exacerbated by the PARP inhibitors, Veliparib and Olpaparib. Since gender differences have been reported in response to Parpl deletion and PARP inhibition [4650], we included both male and female mice in this study. Importantly, we found that WT retinal photoreceptor tissue (but not cerebellar tissue) displays sex-dependent alkylation-induced damage, with WT males being more sensitive than females; this sex difference in alkylationinduced tissue damage is abolished when AAG levels are increased above physiological levels in AagTg mice. Moreover, we show that Olaparib and Veliparib, like the Parpl gene deletion, protect against MMS-induced AAG-dependent retinal and cerebellar damage in both WT and AagTg mice, regardless of gender. Overall, 
our findings further underscore the recent push for investigation and understanding of sex differences in diseases where pathophysiological mechanisms involve PARP1. Moreover, our data are of particular relevance, given the wide range of AAG activity in the human population that we and others have reported $[35,51$, 52]. Neuronal degeneration may represent potential collateral damage when alkylating agents are used for chemotherapy, especially for patients with high AAG activity. The recent surge in the use of PARP inhibitors in combination with alkylating agents $[37,38]$ may represent a powerful tool for obtaining better therapeutic efficacy in cancer treatment, while avoiding the collateral effects of alkylation damage in healthy tissues.

\section{RESULTS}

\section{Treatment with PARP inhibitors protects against MMS-induced retinal degeneration}

We have shown that the AAG DNA glycosylase, an enzyme that initiates BER, drives alkylation-induced cytotoxicity in retinal photoreceptors in WT mice and in a transgenic mouse model ( $\mathrm{Aag} T \mathrm{~g}$ ) expressing increased levels of AAG $[35,36]$. Compared to WT mice, retinal photoreceptors display increased alkylation sensitivity in $\mathrm{AagTg}$ mice and remarkable resistance in $\mathrm{Aag}^{-/-}$mice [35]. This AAG-mediated alkylation sensitivity, for both WT and AagTg mice, is entirely PARP1-dependent, being completely suppressed by Parpl gene deletion [35]. To determine whether drug-mediated PARP inhibition also protects against alkylation-induced retinal degeneration, we treated WT and AagTg mice with either Veliparib $(10 \mathrm{mg} / \mathrm{kg})$ or Olaparib $(50 \mathrm{mg} / \mathrm{kg}) 1$ hour prior to MMS injection $(75 \mathrm{mg} / \mathrm{kg})$, and then analyzed retinas 7 days (d) post-MMS. Gender differences have been reported in response to both Parpl deletion and PARP inhibition [4650]; moreover, differences between Parpl deletion versus PARP inhibition have also been described [53, 54]. We, therefore, grouped the results by gender and compared the effects of PARP inhibition in MMS-treated WT, AagTg, Parp $^{-/-}$and $A a g T g /$ Parp $^{-/-}$mice.

MMS induces selective degeneration of the photoreceptor cells located in the outer nuclear layer (ONL) of the retina $[35,36]$. Retinal degeneration was quantified by counting the rows of photoreceptor nuclei in the ONL on stained histological sections, as described in the Materials and Methods. For all the genotypes, untreated male and female mice have about 11 rows of photoreceptor nuclei. MMS-treated WT males had significantly fewer rows of photoreceptor nuclei, as described previously (Figure 1) $[35,36]$; it should be noted that all our previous studies used male mice exclusively. Here, we found that WT female mice were partially protected from MMS-induced retinal degeneration compared to male mice $(5.2 \pm 0.5$ rows in females versus
$3.1 \pm 0.3$ rows in males, $\mathrm{p}=0.01$, Figure 1$)$. Veliparib treatment partially protected WT mice from MMS-induced retinal degeneration regardless of gender $(6.2 \pm 0.6$ rows in males and $7.8 \pm 0.6$ in females, Figure 1$)$. In contrast, Olaparib treatment did not protect either male or female WT mice (3.5 \pm 0.5 , males; $5.8 \pm 0.6$, females; Figure 1). Veliparib or Olaparib treatment itself induced no retinal damage (Supplementary Figures 1 and 2). Parp1 gene deletion completely rescued the MMS-induced retinal degeneration in male mice, as seen previously [35], and in female Parp $^{-/-}$mice as well (Figure 1).

By comparison with WT, AagTg mice showed extreme retinal sensitivity to MMS treatment, as described previously [35, 36] (Figure 2). Importantly, no difference in MMS sensitivity was observed between male and female $\mathrm{AagTg}$ mice (1.6 \pm 0.2 versus $1.7 \pm 0.1$, Figure 2). Veliparib treatment partially protected $\mathrm{AagTg}$ mice from MMS-induced retinal degeneration, regardless of gender (Figure 2). Notably, protection in AagTg female mice was more robust than in $\mathrm{AagTg}$ male $(7.6 \pm 0.5$ in females versus $4.5 \pm 0.4$ in males, $\mathrm{p}<0.0001)$. In contrast to what we observed in WT, Olaparib treatment partially protected both male and female AagTg mice (4.0 $\pm 0.6, \mathrm{p}=0.002$ and $5.7 \pm 0.4, \mathrm{p}<0.0001$, respectively). As with Veliparib, protection in Olaparib-treated AagTg female mice was slightly more robust than in Olaparib-treated AagTg males $(5.8 \pm 0.4$ in females versus $4.0 \pm 0.6$ in males, $p=0.07$; Figure 2). Greater protection was observed in Veliparibtreated AagTg female mice as compared with Olaparibtreated AagTg female mice ( $7.6 \pm 0.5$ versus $5.7 \pm 0.4, \mathrm{p}$ =0.045; Figure 2). Parpl gene deletion in AagTg mice (Parp $1^{-/} /$AagTg) completely rescued the MMS-induced retinal degeneration, regardless of gender (Figure 2).

Additional groups of mice were treated with PARP inhibitors 1 hour pre- and 24 hours post-MMS injection. Combined pre- and post-MMS treatments with PARP inhibitors (represented as x2 in Supplementary Figures 1 and 2) showed results similar to those obtained with a single pre-MMS treatment, and no additional retinal protection was observed (Supplementary Figures 1 and 2 ). Instead, retinal protection was significantly reduced in AagTg females treated with Veliparib pre- and post-MMS, as compared to AagTg females that received one dose of Veliparib pre-MMS $(5.0 \pm 0.7$ vs $7.7 \pm 0.5, \mathrm{p}<0.05)$.

Our findings demonstrate the following: (i) the retina displays sex-dependent alkylation-induced degeneration with males being more susceptible than females; (ii) the difference in response between males and females is abolished when AAG levels are increased; (iii) PARP inhibitors protect against MMS-induced AAGdependent retinal degeneration but, unlike with the Parp1 deletion, the degree of PARP inhibitor-mediated protection depends on the specific PARP inhibitor used, AAG levels and mouse gender.

MMS treatment causes significant weight loss in both male and female $\mathrm{AagTg}$ mice at 24 hours post- 
treatment, regardless of gender, an effect that is not observed in WT mice (Supplementary Figure 3) [35, 55]. Indeed, 24 hours post-MMS treatment, the body weights (BW) of male and female $\mathrm{AagTg}$ mice were $87.0 \pm 0.9 \%$ and $89.7 \pm 1.4 \%$ of their pre-MMS BW, respectively. Treatment with Veliparib partially protected both male (BW $91.2 \pm 0.9 \%, \mathrm{p}=0.014)$ and female (BW $94.9 \pm 1.1 \%, \mathrm{p}=0.014) \mathrm{AagTg}$ mice from this weight loss, while Olaparib significantly protected male (BW $90.9 \pm 0.5 \%, \mathrm{p}=0.001)$, but not female $(91.3 \pm 1.4 \%$, $\mathrm{p}=0.46)$, AagTg mice. These data further support the protective role of PARP inhibitors against MMS-induced tissue damage.

\section{Estradiol protects wild-type male mice against MMS-induced retinal degeneration}

We have shown that WT female mice are partially protected against MMS-induced retinal degeneration, as compared to male mice. We therefore determined whether estrogen treatment in male mice could protect against MMS-induced retinal degeneration. We treated male and female mice with MMS and delivered daily intraperitoneal injections of 17- $\beta$ estradiol (E2, $50 \mu \mathrm{g} / \mathrm{kg})$. The first dose of E2 was given 2 hours before the single MMS injection, and tissues were collected 7 days post-MMS injection. As shown in Figure 3, the photoreceptors of male mice are more sensitive to MMS than those of female mice (3.3 \pm 0.2 rows in males versus $6.8 \pm 0.5$ rows in females,

A
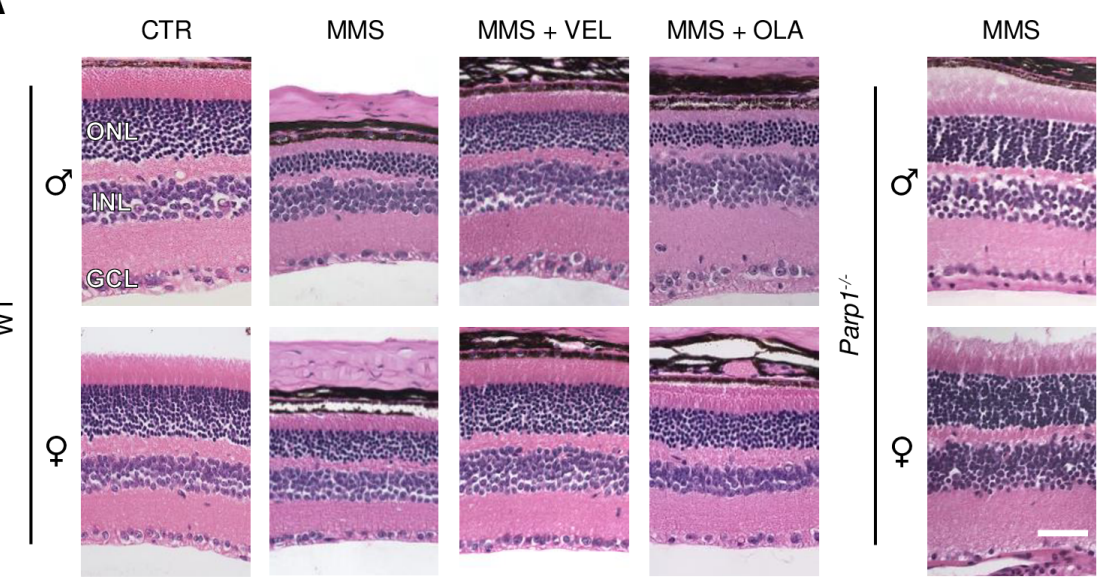

\section{B}

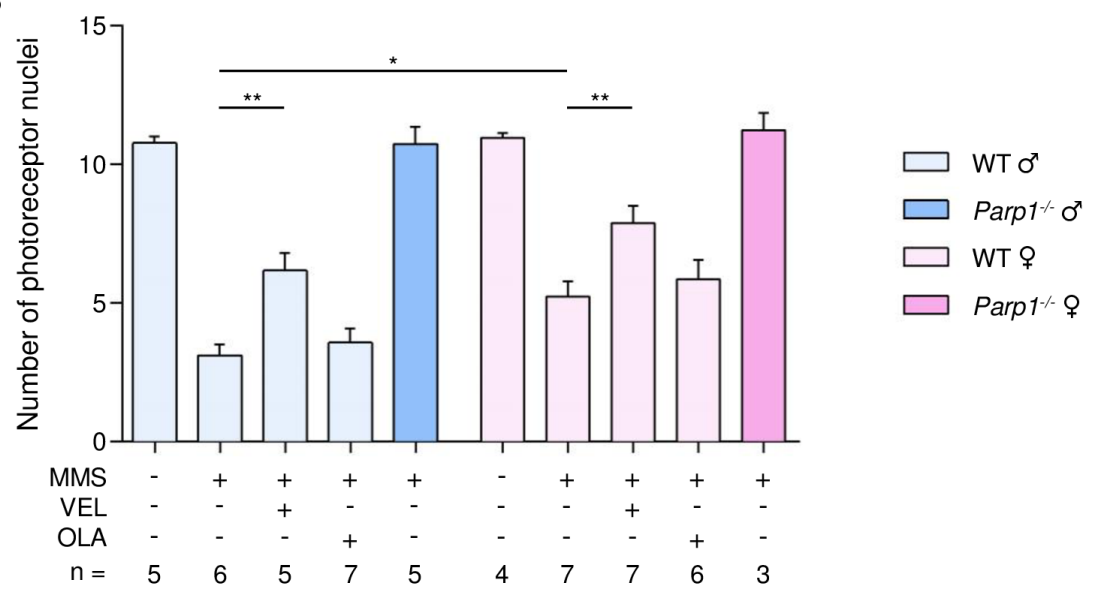

Figure 1: Treatment with PARP inhibitors protects WT mice against sex- and AAG-dependent MMS-induced retinal degeneration. (A) Representative H\&E-stained images of retinas from WT mice and Parp 1/ mice 7 days after MMS (75 mg/kg) and PARP inhibitor (VEL, Veliparib $10 \mathrm{mg} / \mathrm{kg}$; OLA, Olaparib $50 \mathrm{mg} / \mathrm{kg}$ ) treatment, as indicated. PARP inhibitors were administered to WT mice 1 hour prior to MMS treatment. Magnification is 200X (scale bar $50 \mu \mathrm{m}$ ); ONL, outer nuclear layer; INL, inner nuclear layer; GCL, ganglion cell layer; CTR, untreated control mice; $\hat{\partial}$, males; + , females. (B) Quantification of rows of photoreceptor nuclei in the outer nuclear layer of WT and Parp $1^{-/}$mice 7 days after MMS $(75 \mathrm{mg} / \mathrm{kg}$ ) and PARP inhibitors (VEL, Veliparib $10 \mathrm{mg} / \mathrm{kg}$; OLA, Olaparib 50 $\mathrm{mg} / \mathrm{kg}$ ) treatment, as indicated. *, $\mathrm{p}<0.05 ; * *, \mathrm{P}<0.01 ; \hat{\partial}$, males; + , females. 
$\mathrm{p}=0.0001$, Figure 3 ), corroborating the data shown in Figure 1. Figure 3 also shows that E2 protected against MMS-induced retinal degeneration in male mice, but offered no further protection in female mice $(6.2 \pm 0.3$ rows in males; $6.4 \pm 0.5$ in females; Figure 3 ). The sexual dimorphism observed in the retina after MMS treatment is not due to sex-related differences in Aag expression level (Supplementary Figure 4). Our findings suggest a protective role for estrogen against alkylation-induced retinal degeneration in female mice.

\section{Treatment with PARP inhibitors protects against MMS-induced cerebellar degeneration}

MMS induces AAG-dependent cell death in cerebellar granule cells, which comprise 99\% of the granular layer of the cerebellum. This cerebellar degeneration is completely suppressed by Parpl gene deletion [35]. To determine whether PARP inhibition protects against alkylation-induced cerebellar degeneration, we administered Veliparib $(10 \mathrm{mg} / \mathrm{kg})$ or Olaparib (50 mg/kg) to both WT and AagTg mice 1 hour prior to MMS-injection. Due to the dramatically higher MMS sensitivity of AagTg mice compared to WT mice and based on our previous published results [35], in order to induce the degeneration phenotype such that one could accurately quantify the cerebellar degeneration, we used different MMS doses for each genotype: $150 \mathrm{mg} / \mathrm{kg}$ and $60 \mathrm{mg} / \mathrm{kg}$ in WT and AagTg mice, respectively. Cerebella were collected 6 hours post-MMS injection. Cerebellar degeneration was then quantified by counting the number of pyknotic nuclei in the granular layer of the cerebellum, as described in the Materials and Methods. In untreated mice, no pyknotic nuclei were observed (Figures 4 and 5). However, 6 hours post-MMS, we observed severe lesions containing numerous pyknotic nuclei surrounded by white

A
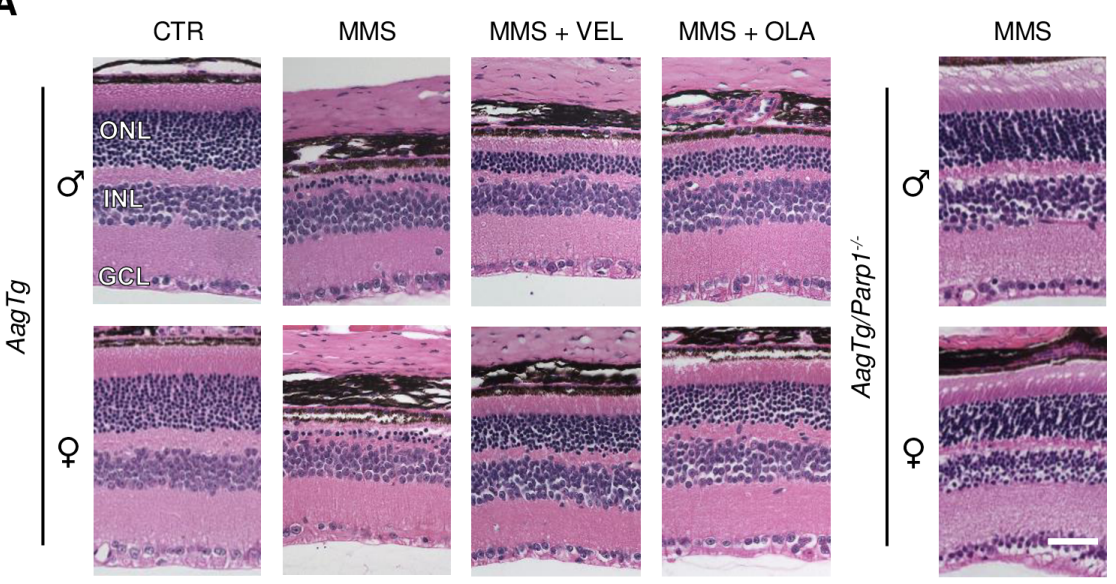

B

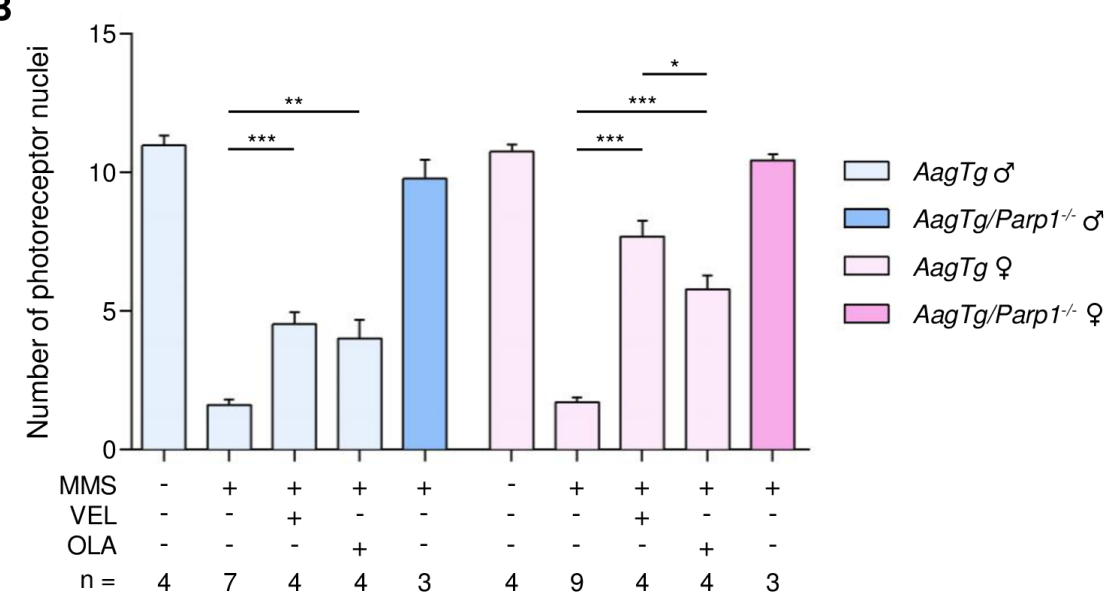

Figure 2: Treatment with PARP inhibitors protects $\mathrm{Aag}$ Tg mice against AAG-dependent MMS-induced retinal degeneration. (A) Representative H\&E-stained images of retinas from $\mathrm{AagTg}$ and $\mathrm{AagTg} / \mathrm{Parp} 1^{-/}$mice $7 \mathrm{days}$ after MMS (75 mg/kg) and PARP inhibitor (VEL, Veliparib $10 \mathrm{mg} / \mathrm{kg}$; OLA, Olaparib $50 \mathrm{mg} / \mathrm{kg}$ ) treatment, as indicated. PARP inhibitors were administered to AagTg mice 1 hour prior to MMS treatment. Magnification is 200X (scale bar $50 \mu \mathrm{m}$ ); ONL, outer nuclear layer; INL, inner nuclear layer; GCL, ganglion cell layer; CTR, untreated control mice; $\widehat{\jmath}$, males; + , females. (B) Quantification of rows of photoreceptor nuclei in the outer nuclear layer of $\mathrm{AagTg}$ and $\mathrm{AagTg} / \mathrm{Parp}^{-/}$mice 7 days after MMS (75 mg/kg) and PARP inhibitor (VEL, Veliparib $10 \mathrm{mg} / \mathrm{kg}$; OLA, Olaparib $50 \mathrm{mg} / \mathrm{kg}$ ) treatment, as indicated. *, p < 0.05; **, $\mathrm{P}<0.01$; **, $\mathrm{p}<0.001$; $\hat{\partial}$, males; + , females. 
space (edema) in WT mice (Figure 4), as shown previously [35]. The number of MMS-induced pyknotic nuclei was similar in male and female WT mice (1332 \pm 179 in males; $1753 \pm 175$ in females, $p=0.11)$. Veliparib treatment $(10$ $\mathrm{mg} / \mathrm{kg}$ ) almost completely rescued WT mice, regardless of sex (Figure 4). Conversely, Olaparib, at the dose of 50 $\mathrm{mg} / \mathrm{kg}$, was able to partially protect male, but not female, WT mice (514 \pm 171 in males and $1325 \pm 405$ in females; Figure 4). Veliparib or Olaparib treatment itself did not induce any cerebellar damage (Supplementary Figure 5).

AagTg mice, despite being exposed to a lower MMS dose, nevertheless experienced similar or increased MMS-induced cerebellar degeneration compared to WT mice (2036 \pm 238 pyknotic nuclei in $\mathrm{AagTg}$ males versus $1332 \pm 179$ in WT males, $\mathrm{p}=0.03 ; 1937 \pm 254$ in $\mathrm{AagTg}$ females versus $1753 \pm 175$ in WT females, $\mathrm{p}=0.54)$. Veliparib treatment $(10 \mathrm{mg} / \mathrm{kg})$ almost completely rescued
AagTg mice, regardless of gender (Figure 5). Olaparib, at the dose of $50 \mathrm{mg} / \mathrm{kg}$, not only did not protect male or female $\mathrm{AagTg}$ mice, but, remarkably, increased the tissue damage in MMS-treated AagTg males while having little effect in females $(2890 \pm 251$ in males, $\mathrm{p}=0.03 ; 1632$ \pm 420 in females, $\mathrm{p}=0.53$; Figure 5). Administration of a much lower Olaparib dose $(1 \mathrm{mg} / \mathrm{kg})$ was able to significantly protect both male and female AagTg mice (Figure 5). Our data suggest that knowledge of PARP inhibitor characteristics, with respect to DNA trapping, and the use of appropriate doses are crucial in order to obtain the desired therapeutic efficacy.

Parpl gene deletion completely rescued MMSinduced cerebellar degeneration in both the WT and AagTg backgrounds, regardless of gender (Figures 4 and 5). Our findings demonstrate that: (i) PARP inhibitors can protect from MMS-induced cerebellar degeneration; (ii)

A
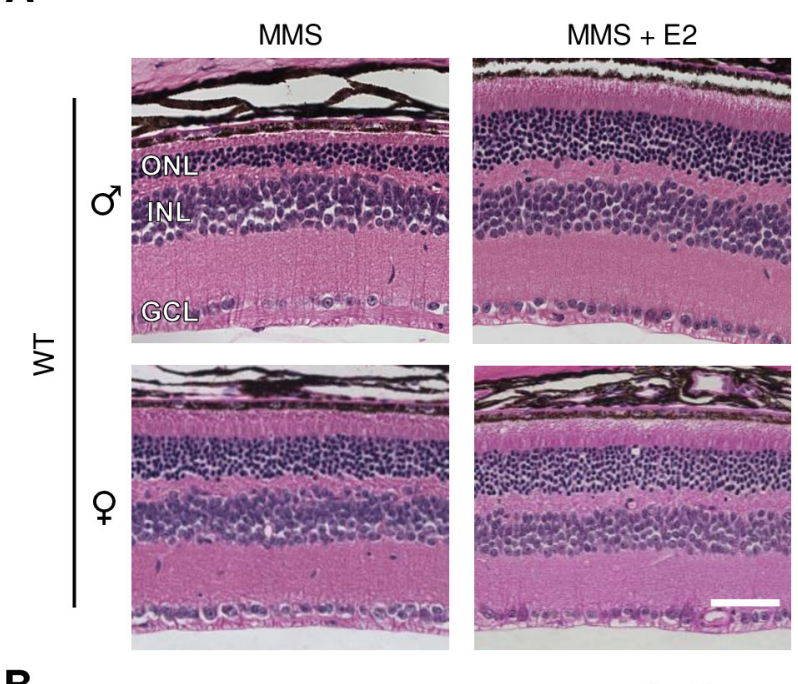

B

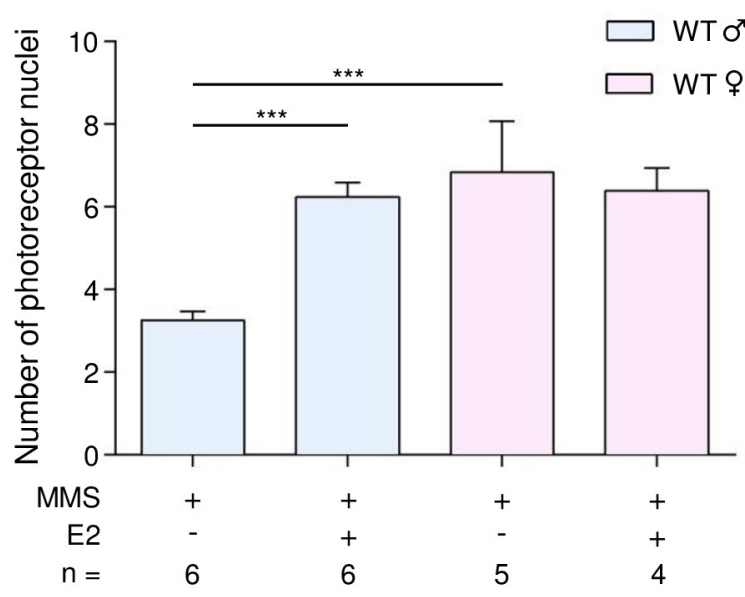

Figure 3: Estradiol protects WT male mice from MMS-induced retinal degeneration. (A) Representative H\&E-stained images of retinas from WT male and female mice treated with 17- $\beta$ estradiol (E2, $50 \mu \mathrm{g} / \mathrm{kg} /$ day) and/or MMS (75 mg/kg), as indicated. E2 was injected 2 hours before MMS injection and daily post-MMS injection. Retinas were harvested 7 days post-MMS injection.

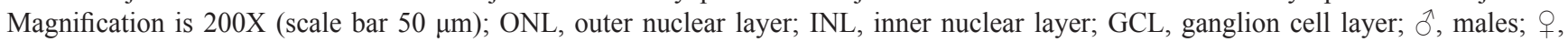
females. (B) Quantification of rows of photoreceptor nuclei in the outer nuclear layer of WT male and female mice, treated or not treated with E2 $(50 \mu \mathrm{g} / \mathrm{kg} /$ day $), 7$ days post-MMS $(75 \mathrm{mg} / \mathrm{kg}) . * * *, \mathrm{p}<0.001 ; \hat{\partial}$, males; + , females. 
as in the retina, unlike the Parpl deletion, the ability of PARP inhibitors to protect against MMS-induced AAGdependent cerebellar degeneration depends on AAG levels and PARP inhibitor properties and doses.

\section{DISCUSSION}

We observed a tissue specific sexual dimorphism after treatment with an alkylating agent. Specifically, MMStreated WT female mice are partially protected against retinal degeneration, as compared with WT male mice, while both sexes exhibit similar cerebellar degeneration. Moreover, treatment of WT male mice with estrogen resulted in protection against MMS-induced retinal degeneration, providing an explanation for the relative resistance to alkylation-induced retinal degeneration in female mice. Gender differences in response to Parpl deletion or PARP inhibition were recently reported using mouse models of cerebral ischemia, endotoxemia and autoimmune nephritis, [46-50, 56]. In particular, it was demonstrated that (i) female mouse models are partially resistant to cerebral ischemia, endotoxemia and autoimmune nephritis; (ii) treatment of male mice with estradiol reduces PARP1 activation and exerts a protective effect against cerebral ischemia, endotoxemia and autoimmune nephritis [46, 47, 50]; (iii) in the absence of functional PARP1, male mice are preferentially protected against cerebral ischemia, endotoxemia and autoimmune nephritis compared to female mice, in which PARP1 deletion/ inhibition offered no benefit in pathological outcome. PARP1 has been shown to interact with the estrogen receptor alpha $(\mathrm{ER} \alpha)$ to form a complex that binds to DNA in vitro [46]. The binding of this ER $\alpha / \mathrm{PARP} 1$ complex to DNA is enhanced by the presence of the estrogen ligand. Thus, it has been proposed that, in females, estrogen may anchor the PARP1/
A

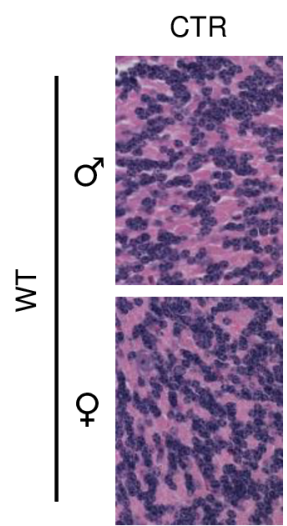

B

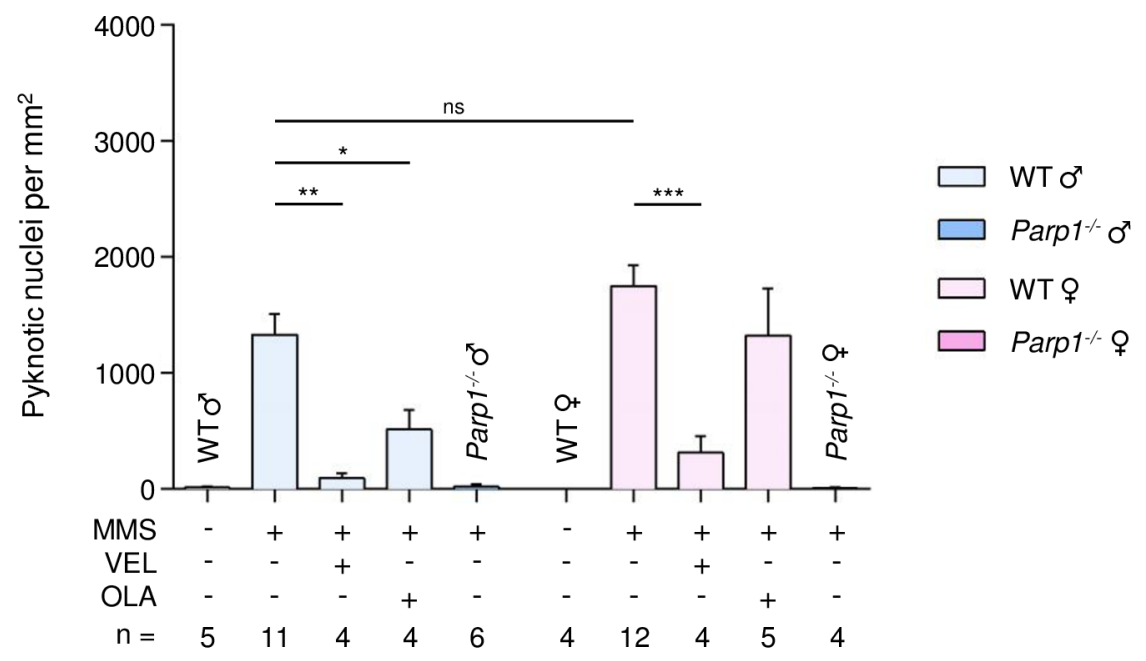

Figure 4: Treatment with PARP inhibitors protects WT mice against AAG-dependent MMS-induced cerebellar degeneration. (A) Representative H\&E-stained images of cerebellar granular cells from WT and Parp 1/ mice 6 hours after MMS (75 $\mathrm{mg} / \mathrm{kg}$ ) treatment. PARP inhibitors (VEL, Veliparib $10 \mathrm{mg} / \mathrm{kg}$; OLA, Olaparib, $50 \mathrm{mg} / \mathrm{kg}$ ) were administered to WT mice $1 \mathrm{hour}$ prior MMS

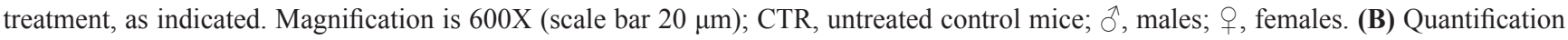
of pyknotic nuclei $/ \mathrm{mm}^{2}$ in WT and Parp $1^{-/}$mice after MMS and PARP inhibitor (VEL, Veliparib $10 \mathrm{mg} / \mathrm{kg}$; OLA, Olaparib $50 \mathrm{mg} / \mathrm{kg}$ ) treatment, as indicated. *, $\mathrm{p}<0.05 ; * *, \mathrm{P}<0.01 ; * * *, \mathrm{p}<0.001$; ns, not statistically significant $(\mathrm{p}=0.11)$; $\hat{O}^{\lambda}$, males; + , females. 
$\mathrm{ER} \alpha$ complex to specific regions of DNA, reducing its availability to access and bind DNA SSBs, thus reducing PARP1 hyperactivation and cell death in the experimental models of disease. PARP1 was also shown to bind and PARylate ER $\alpha$, leading to increased binding of ER $\alpha$ to the estrogen response element within the promoters of target genes, thus promoting ER $\alpha$-mediated transcription [57]; estradiol enhances PARlylation of ER $\alpha$ and $E R \alpha$-mediated transcription. Moreover, $\mathrm{ER} \alpha$ is known to interact with other proteins involved in BER, namely AAG, FEN-1 and APE1 [58]. Binding of ER $\alpha$ with these proteins may influence not only ER $\alpha$-mediated transcription, but also the expression or function of each protein. Expression of ER $\alpha$ has been reported in rodent and human photoreceptors [59, 60]. Together, these findings suggest that a direct interaction between BER proteins, PARP1 in particular, and estrogen receptors could lead to changes in DNA repair, PARP activation and/or gene expression. Such changes presumably underlie the sexual dimorphism of MMS-mediated retinal degeneration we have observed in mice. The known interaction between ER $\alpha$ and protein networks involved in cell fate determination and the oxidative stress response might also contribute to the sexual dimorphism [58]. The protection against alkylation-induced retinal degeneration that we observed in estrogen-treated male mice further supports the proposed model that ER $\alpha$ / estrogen and the PARP1/BER pathways interact, and also confirms the role of estrogen in protecting against alkylationinduced retinal degeneration.

In contrast to the retina, cerebellar degeneration induced by MMS in WT mice was not sexually dimorphic. The fact that ER $\alpha$ expression is lower or absent in the cerebellum $[61,62]$ might explain the lack of sexual

A
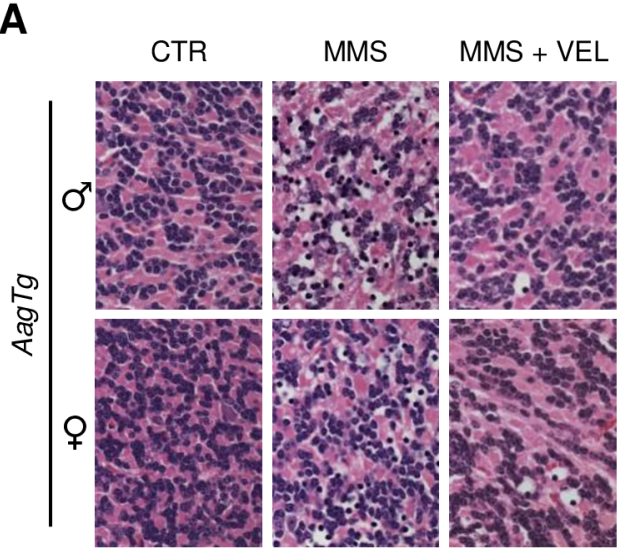

$\mathrm{MMS}+$

OLA Hi

MMS +
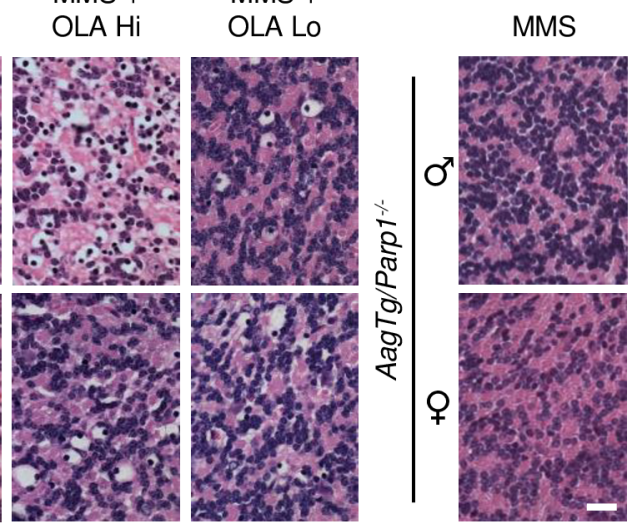

B

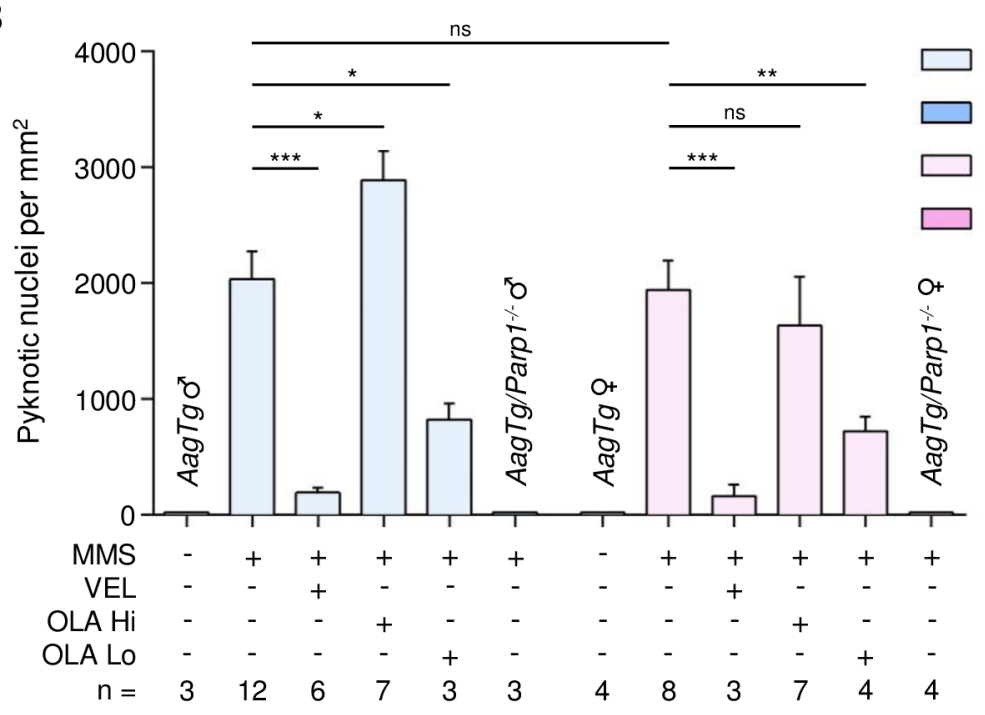

Figure 5: Treatment with PARP inhibitors protects AagTg mice against AAG-dependent MMS-induced cerebellar degeneration. (A) Representative H\&E-stained images of cerebellar granular cells from AagTg and $\mathrm{AagTg} / \mathrm{Parp} 1^{-/}$mice 6 hours after MMS (75 mg/kg) treatment. PARP inhibitors (VEL, Veliparib $10 \mathrm{mg} / \mathrm{kg}$; OLA Hi, Olaparib $50 \mathrm{mg} / \mathrm{kg}$; OLA Lo, Olaparib $1 \mathrm{mg} / \mathrm{kg}$ ) were administered to AagTg mice 1 hour prior MMS treatment. Magnification is $600 \mathrm{X}$ (scale bar $20 \mu \mathrm{m}$ ); CTR, untreated control mice; $\delta$, males; , females. (B) Quantification of pyknotic nuclei/mm² in AagTg and AagTg/Parp 1 ${ }^{-/}$mice after MMS and PARP inhibitor (VEL, Veliparib $10 \mathrm{mg} / \mathrm{kg}$; OLA Hi, Olaparib $50 \mathrm{mg} / \mathrm{kg}$, OLA Lo, Olaparib $1 \mathrm{mg} / \mathrm{kg}$ ) treatment, as indicated. *, p < 0.05; **, P<0.01; ***, p < 0.001; ns, not statistically significant; $\hat{\partial}$, males; $q$, females. 
dimorphism for cerebellar degeneration in MMS-treated WT mice. The AagTg mice show increased MMS-induced retinal and cerebellar degeneration compared to WT mice, as seen previously $[35,36]$. Note that we did not observe any sexual dimorphism in the retinas of MMS-treated AagTg mice; this may be due to the inability of $\operatorname{ER} \alpha$ to compensate for PARP1 hyperactivation due to the higher expression of AAG. In addition, it has been shown that interaction between AAG and ER $\alpha$ causes decreased ER $\alpha$ mediated transcription and increased AAG catalytic activity [63]. Excessive suppression of ER $\alpha$-mediated transcription in AagTg mice might further contribute to the lack of sexual dimorphism in the retinas of AagTg mice. Overall, our data underscore recent arguments for investigating and understanding sex differences in both basic and clinical science [64-67]. Furthermore, the sexually dimorphic response to alkylation-induced damage underscores the importance for sexual-stratification in cancer chemotherapy trials, especially those that utilize alkylating agents.

We found that Parpl gene deletion resulted in complete protection against MMS-induced retinal and cerebellar degeneration in both WT and AagTg mice, regardless of gender. It has been described previously that female and male mice exhibit different responses to Parpl deletion in other mouse models of disease. Indeed, Parp1 deletion has been shown to protect male, but not female, animals against stroke and autoimmune-nephritis [47-50, 68]. A sex-specific bias for distinct cell death pathways in some tissues might account for the sexually dimorphic response to Parpl deletion observed in these experimental models. It appears that, upon specific kinds of stress, female cells preferentially activate an apoptotic pathway while male cells favor a PARP1-dependent necrotic pathway [69-71]. It is well known that DNA alkylating agents can induce necrosis in a PARP1-dependent manner, although this is likely to be cell type-dependent [72-74]. Even though female mice are partially protected against alkylation-induced retinal degeneration compared to male mice, Parp 1 gene deletion completely rescued both males and females against alkylation-induced retinal and cerebellar degeneration. We hypothesized that alkylation treatment induces retinal and cerebellar degeneration via the PARP1-dependent necrotic pathway in both males and females, but that female photoreceptors are just more resistant to such necrosis.

We found that treatment with PARP inhibitors also protects against MMS-induced AAG-dependent neuronal damage, but their efficacy depends mainly on their chemistry and dosage. Indeed, Veliparib, at a dose of $10 \mathrm{mg} / \mathrm{kg}$, was able to protect against MMS-induced retinal and cerebellar degeneration in both WT and AagTg mice regardless of the gender, whereas Olaparib, at a dose of $50 \mathrm{mg} / \mathrm{kg}$, was able to significantly protect only AagTg mice from retinal degeneration and WT male mice from cerebellar degeneration. Moreover, the extent of protection after Olaparib treatment was consistently lower than that observed after Veliparib treatment. It has been shown that, in addition to catalytic inhibition, some PARP inhibitors can induce cytotoxic PARP-DNA complexes, most likely by enhancing the crosslink between PARP and AP sites, or by inducing a PARP conformational change that traps PARP at the site of damage [39, 41, $44,75]$. Such trapping would interfere with DNA repair, replication and transcription. The formation of such a toxic complex appears to be a suicidal event when BER is overwhelmed, as can be the case with MMS treatment [41-43]. The potency in trapping PARP differs markedly among PARP inhibitors and it is not correlated with the catalytic inhibitory properties of each drug [39]. Therefore, PARP inhibitors can produce two competing effects: (i) resistance to MMS-induced cell death by PARP catalytic inhibition that prevents $\mathrm{NAD}^{+} / \mathrm{ATP}$ depletion, or (ii) sensitivity to MMS-induced necrotic cell death by trapping of PARP on DNA. Even though Olaparib has a higher catalytic inhibition activity, it also has much higher PARP-DNA trapping activity compared to Veliparib, thus making Olaparib a more potent cytotoxic compound than Veliparib [39]. As previously stated, in contrast to Veliparib, we observed absent or reduced Olaparib protection against MMS-induced neuronal degeneration, which may be due to Olaparib's higher PARP-DNA trapping activity. Notably, Olaparib treatment $(50 \mathrm{mg} /$ $\mathrm{kg}$ ) resulted in increased, rather than decreased, MMSinduced cerebellar degeneration in AagTg male mice. We hypothesize that the increased AAG activity in AagTg mice might lead to many more AP sites and SSBs and, thus, more substrate for Olaparib PARP-DNA trapping activity. Administration of a much lower dose of Olaparib $(1 \mathrm{mg} / \mathrm{kg}$ ) in $\mathrm{AagTg}$ mice resulted in protection against MMS-induced cerebellar degeneration in both males and females, supporting our hypothesis and suggesting that knowledge of PARP inhibitor properties and use of appropriate dosages is necessary to obtain therapeutic efficacy. Even so, protection against MMS-induced cerebellar degeneration after treatment with low doses of Olaparib $(1 \mathrm{mg} / \mathrm{kg}$ ) was still not at the level observed after Veliparb treatment $(10 \mathrm{mg} / \mathrm{kg})$ further suggesting that PARP inhibitors with less trapping activity, such as Veliparib, are more efficacious at preventing alkylationinduced neuronal degeneration. Finally, an additional dose of PARP inhibitors 24 hours after MMS treatment did not result in increased efficacy for either compound and, notably, in the case of Veliparib, resulted in reduced protection against retinal degeneration in female $\mathrm{AagTg}$ mice, suggesting that a single dose pre-MMS treatment is sufficient for therapeutic efficacy and additional doses may only cause increased damage due to PARP-DNA trapping activity.

In addition to protecting against neuronal degeneration, PARP inhibitors also protect $\mathrm{AagTg}$ mice against alkylation-induced body weight loss, regardless of the gender. We have shown that AAG mediates 
MMS-induced whole-animal lethality accompanied by cytotoxicity in organs other than retina and cerebellum [35]. Therefore, PARP inhibitors might also exert a protective effect in several other organs resulting in reduced overall weight loss.

Taken together, our data show that low doses of PARP inhibitors, or PARP inhibitors with less PARP-DNA trapping ability, can protect against alkylation induced neuronal degeneration. Alkylating agents are commonly used in cancer therapy. It is possible that the alkylationinduced neuronal degeneration and organ toxicity we observed in mice $[35,36]$ could be a rate-limiting side effect of alkylating agents used in cancer chemotherapy. Given the wide inter-individual variability of AAG [35, 51, 52] and PARP1 activity [76] in human populations and the sexual dimorphism we observed, toxicity might be limited to particular subpopulations, making it difficult to generalize. Nevertheless, our findings in mice may potentially prove to have important clinical relevance.

PARP inhibitors are used in a clinical setting for the treatment of various tumors, either alone or in combination with other chemotherapeutics, including alkylating agents $[37,38]$. PARP inhibitors allow selective killing of cancer cells because the trapping/cytotoxic effect makes use of deficiencies in DNA repair systems that are unique to individual types of cancer (e.g. BRCA1/BRCA2-deficient tumors), as compared with normal tissue [40, 77-79]. PARP inhibitor cytotoxicity is enhanced when they are combined with alkylating agents [41-43]. Therefore, the recent surge in the use of PARP inhibitors in combination with alkylating agents might represent a powerful tool for obtaining better therapeutic efficacy in cancer treatment, while avoiding the collateral effects of alkylating agents in healthy tissues of the subpopulations mentioned above. Moreover, our findings suggest that low doses of PARP inhibitors, or PARP inhibitors with less DNA trapping ability, might also be used to treat neurodegenerative disorders that involve PARP1 activation [80, 81], and that it would be worthwhile to identify PARP inhibitors with little or no PARP-DNA trapping activity.

\section{MATERIALS AND METHODS}

\section{Animals and treatments}

Aag transgenic (AagTg) mice were described

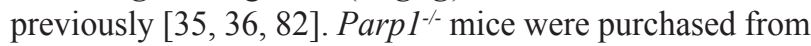
Jackson Laboratories [83] and backcrossed to C57BL/6. WT and AagTg mice were on a C57BL/6 genetic background. Parp $1^{-/}$and AagTg/Parp1 $1^{-/}$mice were on mixed genetic background (C57BL/6:129S). All animal procedures were performed according the NIH guide for the Care and Use of Laboratory Animals.

MMS was injected intraperitoneally. Veliparib (Selleck Chemichals Inc) was administered by oral gavage (10 mg/kg) and Olaparib (Selleck Chemicals Inc) by intraperitoneal injections (50 mg/kg or $1 \mathrm{mg} / \mathrm{kg}$ ). PARP inhibitor doses were chosen based on datasheet guidelines and previously published data $[84,85]$. 17- $\beta$ estradiol (E2, Sigma) was injected intraperitoneally. For experiments in the retina, where indicated, mice received daily E2 doses of $50 \mu \mathrm{g} / \mathrm{kg}$.

\section{Histological analysis}

Eyes were fixed in Carnoy's fixative and brains in $10 \%$ formalin. Tissues were processed by the Histology Core Facility at the David H. Koch Institute for Integrative Cancer Research (MIT); they were paraffin-embedded, sectioned at $5 \mu \mathrm{m}$, and stained with hematoxylin and eosin (H\&E). All H\&E-stained slides were blindly analyzed using a Nikon Eclipse 6800 microscope, a Retiga Exi camera, Velocity and ImageJ softwares.

To quantify retinal degeneration, the number of rows of photoreceptor nuclei in the outer nuclear layer (ONL) of each eye was counted. A minimum of three sections, close to the optic nerve area, was analyzed for each eye. For each section, the number of row of photoreceptor nuclei in the ONL was counted at three different points along the retina and averaged. The averaged counts for each of the three sections were then averaged for each eye. All eyes in an experimental group were then averaged and standard errors calculated. To quantify cerebellar degeneration, images representative of each lobe in the cerebellum were taken. For each cerebellum, the number of pyknotic nuclei $/ \mathrm{mm}^{2}$ in each lobe was counted and then averaged. The counts from each group were then averaged, and standard errors calculated.

\section{Statistics}

Statistical analyses were performed using GraphPad Prism software. Statistical significance was determined using unpaired t-test. A p-value is considered significant if less than 0.05 .

\section{Abbreviations}

$O^{6} \mathrm{meG}: O^{6}$-methylguanine

7meG: 7-methylguanine

3meA: 3-methyladenine

BER: base excision repair pathway

AAG: alkyladenine DNA glycosylase

APE1: apurinic/apyrimidinic endonuclease

SSB: DNA single-strand break

Pol ß: DNA polymerase $\beta$

5'dRP: 5'deoxyribose-5-phosphate termini

PARP1: poly(ADP-ribose) polymerase 1

NAD+: nicotinamide adenine dinucleotide

PAR: polymers of ADP-ribose

XRCC1: X-ray repair cross-complementing protein 1

ATP: adenosine triphosphate

MMS: methyl methanesulfonate 
DSB: DNA double-strand break

E2: 17-ß estradiol

ER $\alpha$ : estrogen receptor alpha

FEN-1: flap endonuclease 1

\section{Author contributions}

Conception and design: M.A., L.D.S.; Investigation: M.A., J.J.C., K.R.F., J.A.C.; Analysis and interpretation of data: M.A., J.J.C., K.R.F.; Writing and editing: M.A., L.D.S.; Project administration: M.A., L.D.S; Funding acquisition: L.D.S.

\section{ACKNOWLEDGMENTS}

We thank the Hope Babette Tang Histology Core at the David H. Koch Institute for Integrative Cancer Research for technical help.

\section{CONFLICTS OF INTEREST}

The authors declare that no conflicts of interest exists.

\section{FUNDING}

This work was supported by NIH grants R01CA075576, R01-CA055042, P30-ES02109 and P30CA014051. L.D.S is an American Cancer Society Research Professor and an Ellison Medical Foundation Senior Scholar.

\section{REFERENCES}

1. Fu D, Calvo JA, Samson LD. Balancing repair and tolerance of DNA damage caused by alkylating agents. Nat Rev Cancer. 2012; 12:104-120.

2. Robertson AB, Klungland A, Rognes T, Leiros I. DNA repair in mammalian cells: Base excision repair: the long and short of it. Cell Mol Life Sci. 2009; 66:981-993.

3. Lan L, Nakajima S, Oohata Y, Takao M, Okano S, Masutani M, Wilson SH, Yasui A. In situ analysis of repair processes for oxidative DNA damage in mammalian cells. Proc Natl Acad Sci U S A. 2004; 101:13738-13743.

4. Caldecott KW. Single-strand break repair and genetic disease. Nat Rev Genet. 2008; 9:619-631.

5. Dantzer F, de La Rubia G, Menissier-De Murcia J, Hostomsky Z, de Murcia G, Schreiber V. Base excision repair is impaired in mammalian cells lacking poly(ADPribose) polymerase-1. Biochemistry. 2000; 39:7559-7569.

6. Fisher AE, Hochegger H, Takeda S, Caldecott KW. Poly(ADP-ribose) polymerase 1 accelerates singlestrand break repair in concert with poly(ADP-ribose) glycohydrolase. Mol Cell Biol. 2007; 27:5597-5605.
7. Woodhouse BC, Dianova, II, Parsons JL, Dianov GL. Poly(ADP-ribose) polymerase-1 modulates DNA repair capacity and prevents formation of DNA double strand breaks. DNA Repair (Amst). 2008; 7:932-940.

8. Lavrik OI, Prasad R, Sobol RW, Horton JK, Ackerman EJ, Wilson SH. Photoaffinity labeling of mouse fibroblast enzymes by a base excision repair intermediate. Evidence for the role of poly(ADP-ribose) polymerase-1 in DNA repair. J Biol Chem. 2001; 276:25541-25548.

9. Schreiber V, Dantzer F, Ame JC, de Murcia G. Poly(ADPribose): novel functions for an old molecule. Nat Rev Mol Cell Biol. 2006; 7:517-528.

10. Krishnakumar R, Gamble MJ, Frizzell KM, Berrocal JG, Kininis M, Kraus WL. Reciprocal binding of PARP-1 and histone $\mathrm{H} 1$ at promoters specifies transcriptional outcomes. Science. 2008; 319:819-821.

11. Bai P, Virág L. Role of poly(ADP-ribose) polymerases in the regulation of inflammatory processes. FEBS Lett. 2012; 586:3771-3777.

12. Luo X, Kraus WL. On PAR with PARP: cellular stress signaling through poly(ADP-ribose) and PARP-1. Genes Dev. 2012; 26:417-432.

13. Satoh MS, Lindahl T. Role of poly(ADP-ribose) formation in DNA repair. Nature. 1992; 356:356-358.

14. Kraus WL, Lis JT. PARP goes transcription. Cell. 2003; 113:677-683.

15. Ahel D, Hořejší Z, Wiechens N, Polo SE, Garcia-Wilson E, Ahel I, Flynn H, Skehel M, West SC, Jackson SP, OwenHughes T, Boulton SJ. Poly(ADP-ribose)-dependent regulation of DNA repair by the chromatin remodeling enzyme ALC1. Science. 2009; 325:1240-1243.

16. Timinszky G, Till S, Hassa PO, Hothorn M, Kustatscher G, Nijmeijer B, Colombelli J, Altmeyer M, Stelzer EH, Scheffzek $\mathrm{K}$, Hottiger MO, Ladurner AG. A macrodomain-containing histone rearranges chromatin upon sensing PARP1 activation. Nat Struct Mol Biol. 2009; 16:923-929.

17. Gottschalk AJ, Timinszky G, Kong SE, Jin J, Cai Y, Swanson SK, Washburn MP, Florens L, Ladurner AG, Conaway JW, Conaway RC. Poly(ADP-ribosyl)ation directs recruitment and activation of an ATP-dependent chromatin remodeler. Proc Natl Acad Sci U S A. 2009; 106:13770-13774.

18. El-Khamisy SF, Masutani M, Suzuki H, Caldecott KW. A requirement for PARP-1 for the assembly or stability of XRCC1 nuclear foci at sites of oxidative DNA damage. Nucleic Acids Res. 2003; 31:5526-5533.

19. Masson M, Niedergang C, Schreiber V, Muller S, Menissier-de Murcia J, de Murcia G. XRCC1 is specifically associated with poly(ADP-ribose) polymerase and negatively regulates its activity following DNA damage. Mol Cell Biol. 1998; 18:3563-3571.

20. Vidal AE, Boiteux S, Hickson ID, Radicella JP. XRCC1 coordinates the initial and late stages of DNA abasic site repair through protein-protein interactions. EMBO J. 2001; 20:6530-6539. 
21. Mortusewicz O, Fouquerel E, Ame JC, Leonhardt H, Schreiber V. PARG is recruited to DNA damage sites through poly(ADP-ribose)- and PCNA-dependent mechanisms. Nucleic Acids Res. 2011; 39:5045-5056.

22. Boiteux S, Guillet M. Abasic sites in DNA: repair and biological consequences in Saccharomyces cerevisiae. DNA Repair (Amst). 2004; 3:1-12.

23. Schaaper RM, Kunkel TA, Loeb LA. Infidelity of DNA synthesis associated with bypass of apurinic sites. Proc Natl Acad Sci U S A. 1983; 80:487-491.

24. Pagès V, Johnson RE, Prakash L, Prakash S. Mutational specificity and genetic control of replicative bypass of an abasic site in yeast. Proc Natl Acad Sci U S A. 2008; 105:1170-1175

25. Avkin S, Adar S, Blander G, Livneh Z. Quantitative measurement of translesion replication in human cells: evidence for bypass of abasic sites by a replicative DNA polymerase. Proc Natl Acad Sci U S A. 2002; 99:3764-3769.

26. Strauss BS. The 'A rule' of mutagen specificity: a consequence of DNA polymerase bypass of noninstructional lesions? Bioessays. 1991; 13:79-84.

27. Ha HC, Snyder SH. Poly(ADP-ribose) polymerase is a mediator of necrotic cell death by ATP depletion. Proc Natl Acad Sci U S A. 1999; 96:13978-13982.

28. Heeres JT, Hergenrother PJ. Poly(ADP-ribose) makes a date with death. Curr Opin Chem Biol. 2007; 11:644-653.

29. Cipriani G, Rapizzi E, Vannacci A, Rizzuto R, Moroni F, Chiarugi A. Nuclear poly(ADP-ribose) polymerase-1 rapidly triggers mitochondrial dysfunction. J Biol Chem. $2005 ; 280: 17227-17234$.

30. Alano CC, Garnier P, Ying W, Higashi Y, Kauppinen TM, Swanson RA. NAD+ depletion is necessary and sufficient for poly(ADP-ribose) polymerase-1-mediated neuronal death. J Neurosci. 2010; 30:2967-2978.

31. Fouquerel E, Goellner EM, Yu Z, Gagne JP, Barbi de Moura M, Feinstein T, Wheeler D, Redpath P, Li J, Romero G, Migaud M, Van Houten B, Poirier GG, Sobol RW. ARTD1/ PARP1 negatively regulates glycolysis by inhibiting hexokinase 1 independent of NAD+ depletion. Cell Rep. 2014; 8:1819-1831.

32. Wang Y, Kim NS, Haince JF, Kang HC, David KK, Andrabi SA, Poirier GG, Dawson VL, Dawson TM. Poly(ADPribose) (PAR) binding to apoptosis-inducing factor is critical for PAR polymerase-1-dependent cell death (parthanatos). Sci Signal. 2011; 4:ra20.

33. Yu SW, Wang H, Poitras MF, Coombs C, Bowers WJ, Federoff HJ, Poirier GG, Dawson TM, Dawson VL. Mediation of poly(ADP-ribose) polymerase-1-dependent cell death by apoptosis-inducing factor. Science. 2002; 297:259-263.

34. Artus C, Boujrad H, Bouharrour A, Brunelle MN, Hoos $\mathrm{S}$, Yuste VJ, Lenormand P, Rousselle JC, Namane A, England P, Lorenzo HK, Susin SA. AIF promotes chromatinolysis and caspase-independent programmed necrosis by interacting with histone H2AX. EMBO J. 2010; 29:1585-1599.

35. Calvo JA, Moroski-Erkul CA, Lake A, Eichinger LW, Shah D, Jhun I, Limsirichai P, Bronson RT, Christiani DC, Meira LB, Samson LD. Aag DNA glycosylase promotes alkylation-induced tissue damage mediated by Parp1. PLoS Genet. 2013; 9:e1003413.

36. Meira LB, Moroski-Erkul CA, Green SL, Calvo JA, Bronson RT, Shah D, Samson LD. Aag-initiated base excision repair drives alkylation-induced retinal degeneration in mice. Proc Natl Acad Sci U S A. 2009; 106:888-893.

37. Underhill C, Toulmonde M, Bonnefoi H. A review of PARP inhibitors: from bench to bedside. Ann Oncol. 2011; 22:268-279.

38. Javle M, Curtin NJ. The role of PARP in DNA repair and its therapeutic exploitation. Br J Cancer. 2011; 105:1114-1122.

39. Murai J, Huang SY, Das BB, Renaud A, Zhang Y, Doroshow JH, Ji J, Takeda S, Pommier Y. Trapping of PARP1 and PARP2 by clinical PARP inhibitors. Cancer Res. 2012; 72:5588-5599.

40. Helleday T. The underlying mechanism for the PARP and BRCA synthetic lethality: clearing up the misunderstandings. Mol Oncol. 2011; 5:387-393.

41. Kedar PS, Stefanick DF, Horton JK, Wilson SH. Increased PARP-1 association with DNA in alkylation damaged, PARP-inhibited mouse fibroblasts. Mol Cancer Res. 2012; 10:360-368.

42. Horton JK, Wilson SH. Predicting enhanced cell killing through PARP inhibition. Mol Cancer Res. 2013; 11:13-18.

43. Horton JK, Wilson SH. Strategic combination of DNAdamaging agent and PARP inhibitor results in enhanced cytotoxicity. Front Oncol. 2013; 3:257.

44. Prasad R, Horton JK, Chastain PD 2nd, Gassman NR, Freudenthal BD, Hou EW, Wilson SH. Suicidal crosslinking of PARP-1 to AP site intermediates in cells undergoing base excision repair. Nucleic Acids Res. 2014; 42:6337-6351.

45. Chalmers AJ. The potential role and application of PARP inhibitors in cancer treatment. Br Med Bull. 2009; 89:23-40.

46. Mabley JG, Horvath EM, Murthy KG, Zsengeller Z, Vaslin A, Benko R, Kollai M, Szabo C. Gender differences in the endotoxin-induced inflammatory and vascular responses: potential role of poly(ADP-ribose) polymerase activation. J Pharmacol Exp Ther. 2005; 315:812-820.

47. McCullough LD, Zeng Z, Blizzard KK, Debchoudhury I, Hurn PD. Ischemic nitric oxide and poly (ADP-ribose) polymerase-1 in cerebral ischemia: male toxicity, female protection. J Cereb Blood Flow Metab. 2005; 25:502-512.

48. Yuan M, Siegel C, Zeng Z, Li J, Liu F, McCullough LD. Sex differences in the response to activation of the poly (ADP-ribose) polymerase pathway after experimental stroke. Exp Neurol. 2009; 217:210-218. 
49. Hagberg $\mathrm{H}$, Wilson MA, Matsushita H, Zhu C, Lange M, Gustavsson M, Poitras MF, Dawson TM, Dawson VL, Northington F, Johnston MV. PARP-1 gene disruption in mice preferentially protects males from perinatal brain injury. J Neurochem. 2004; 90:1068-1075.

50. Jog NR, Dinnall JA, Gallucci S, Madaio MP, Caricchio R. Poly(ADP-ribose) polymerase-1 regulates the progression of autoimmune nephritis in males by inducing necrotic cell death and modulating inflammation. J Immunol. 2009; 182:7297-7306.

51. Crosbie PA, Watson AJ, Agius R, Barber PV, Margison GP, Povey AC. Elevated N3-methylpurine-DNA glycosylase DNA repair activity is associated with lung cancer. Mutat Res. 2012; 732:43-46.

52. Leitner-Dagan Y, Sevilya Z, Pinchev M, Kremer R, Elinger D, Rennert HS, Schechtman E, Freedman L, Rennert G, Livneh Z, Paz-Elizur T. Enzymatic MPG DNA repair assays for two different oxidative DNA lesions reveal associations with increased lung cancer risk. Carcinogenesis. 2014; 35:2763-2770.

53. Godon C, Cordelières FP, Biard D, Giocanti N, MégninChanet F, Hall J, Favaudon V. PARP inhibition versus PARP-1 silencing: different outcomes in terms of singlestrand break repair and radiation susceptibility. Nucleic Acids Res. 2008; 36:4454-4464.

54. Hoch NC, Hanzlikova H, Rulten SL, Tetreault M, Komulainen E, Ju L, Hornyak P, Zeng Z, Gittens W, Rey SA, Staras K, Mancini GM, McKinnon PJ, et al. XRCC1 mutation is associated with PARP1 hyperactivation and cerebellar ataxia. Nature. 2017; 541:87-91.

55. Calvo JA, Allocca M, Fake KR, Muthupalani S, Corrigan JJ, Bronson RT, Samson LD. Parp1 protects against Aagdependent alkylation-induced nephrotoxicity in a sexdependent manner. Oncotarget. 2016; 7: 44950-44965. https://doi.org/10.18632/oncotarget.10440.

56. Siegel CS, McCullough LD. NAD + and nicotinamide: sex differences in cerebral ischemia. Neuroscience. 2013; 237:223-231.

57. Zhang F, Wang Y, Wang L, Luo X, Huang K, Wang C, Du M, Liu F, Luo T, Huang D. Poly(ADP-ribose) polymerase 1 is a key regulator of estrogen receptor alpha-dependent gene transcription. J Biol Chem. 2013; 288:11348-11357.

58. Schultz-Norton JR, Ziegler YS, Nardulli AM. ER $\alpha$ associated protein networks. Trends Endocrinol Metab. 2011; 22:124-129.

59. Cascio C, Russo D, Drago G, Galizzi G, Passantino R, Guarneri R, Guarneri P. 17beta-estradiol synthesis in the adult male rat retina. Exp Eye Res. 2007; 85:166-172.

60. Ogueta SB, Schwartz SD, Yamashita CK, Farber DB. Estrogen receptor in the human eye: influence of gender and age on gene expression. Invest Ophthalmol Vis Sci. 1999; 40:1906-1911.

61. Mitra SW, Hoskin E, Yudkovitz J, Pear L, Wilkinson HA, Hayashi S, Pfaff DW, Ogawa S, Rohrer SP, Schaeffer JM,
McEwen BS, Alves SE. Immunolocalization of estrogen receptor beta in the mouse brain: comparison with estrogen receptor alpha. Endocrinology. 2003; 144:2055-2067.

62. Guo XZ, Su JD, Sun QW, Jiao BH. Expression of estrogen receptor (ER) -alpha and -beta transcripts in the neonatal and adult rat cerebral cortex, cerebellum, and olfactory bulb. Cell Res. 2001; 11:321-324.

63. Likhite VS, Cass EI, Anderson SD, Yates JR, Nardulli AM. Interaction of estrogen receptor alpha with 3-methyladenine DNA glycosylase modulates transcription and DNA repair. J Biol Chem. 2004; 279:16875-16882.

64. Baggio G, Corsini A, Floreani A, Giannini S, Zagonel V. Gender medicine: a task for the third millennium. Clin Chem Lab Med. 2013; 51: 713-727.

65. Miller VM, Bahn RS. Mentoring interdisciplinary research teams for the study of sex and gender differences in health and disease. Glob Adv Health Med. 2013; 2:109-112.

66. Yoon DY, Mansukhani NA, Stubbs VC, Helenowski IB, Woodruff TK, Kibbe MR. Sex bias exists in basic science and translational surgical research. Surgery. 2014; 156:508-516.

67. Beery AK, Zucker I. Sex bias in neuroscience and biomedical research. Neurosci Biobehav Rev. 2011; 35:565-572.

68. Liu F, Lang J, Li J, Benashski SE, Siegel M, Xu Y, McCullough LD. Sex differences in the response to poly(ADP-ribose) polymerase-1 deletion and caspase inhibition after stroke. Stroke. 2011; 42:1090-1096.

69. Du L, Bayir H, Lai Y, Zhang X, Kochanek PM, Watkins SC, Graham SH, Clark RS. Innate gender-based proclivity in response to cytotoxicity and programmed cell death pathway. J Biol Chem. 2004; 279:38563-38570.

70. Jog NR, Caricchio R. Differential regulation of cell death programs in males and females by Poly (ADP-Ribose) Polymerase-1 and $17 \beta$ estradiol. Cell Death Dis. 2013; 4:e758.

71. Sharma J, Nelluru G, Wilson MA, Johnston MV, Hossain MA. Sex-specific activation of cell death signalling pathways in cerebellar granule neurons exposed to oxygen glucose deprivation followed by reoxygenation. ASN Neuro. 2011; 3.

72. Zong WX, Ditsworth D, Bauer DE, Wang ZQ, Thompson CB. Alkylating DNA damage stimulates a regulated form of necrotic cell death. Genes Dev. 2004; 18:1272-1282.

73. Sosna J, Voigt S, Mathieu S, Lange A, Thon L, Davarnia P, Herdegen T, Linkermann A, Rittger A, Chan FK, Kabelitz D, Schutze S, Adam D. TNF-induced necroptosis and PARP-1-mediated necrosis represent distinct routes to programmed necrotic cell death. Cell Mol Life Sci. 2014; 71:331-348.

74. Fu D, Jordan JJ, Samson LD. Human ALKBH7 is required for alkylation and oxidation-induced programmed necrosis. Genes Dev. 2013; 27:1089-1100. 
75. Strom CE, Johansson F, Uhlen M, Szigyarto CA, Erixon $\mathrm{K}$, Helleday T. Poly (ADP-ribose) polymerase (PARP) is not involved in base excision repair but PARP inhibition traps a single-strand intermediate. Nucleic Acids Res. 2011; 39:3166-3175.

76. Zaremba T, Thomas HD, Cole M, Coulthard SA, Plummer ER, Curtin NJ. Poly(ADP-ribose) polymerase-1 (PARP1) pharmacogenetics, activity and expression analysis in cancer patients and healthy volunteers. Biochem J. 2011; 436:671-679.

77. Anders CK, Winer EP, Ford JM, Dent R, Silver DP, Sledge GW, Carey LA. Poly(ADP-Ribose) polymerase inhibition: "targeted" therapy for triple-negative breast cancer. Clin Cancer Res. 2010; 16:4702-4710.

78. Javle M, Curtin NJ. The potential for poly (ADP-ribose) polymerase inhibitors in cancer therapy. Ther Adv Med Oncol. 2011; 3:257-267.

79. Lord CJ, Ashworth A. PARP inhibitors: synthetic lethality in the clinic. Science. 2017; 355:1152-1158.

80. Ross CA, Truant R. DNA repair: a unifying mechanism in neurodegeneration. Nature. 2017; 541:34-35.

81. Kauppinen TM, Swanson RA. The role of poly(ADPribose) polymerase-1 in CNS disease. Neuroscience. 2007; 145:1267-1272.
82. Engelward BP, Weeda G, Wyatt MD, Broekhof JL, de Wit J, Donker I, Allan JM, Gold B, Hoeijmakers JH, Samson LD. Base excision repair deficient mice lacking the Aag alkyladenine DNA glycosylase. Proc Natl Acad Sci U S A. 1997; 94:13087-13092.

83. Wang ZQ, Auer B, Stingl L, Berghammer H, Haidacher D, Schweiger M, Wagner EF. Mice lacking ADPRT and poly(ADP-ribosyl)ation develop normally but are susceptible to skin disease. Genes Dev. 1995; 9:509-520.

84. Rottenberg S, Jaspers JE, Kersbergen A, van der Burg E, Nygren AO, Zander SA, Derksen PW, de Bruin M, Zevenhoven J, Lau A, Boulter R, Cranston A, O'Connor MJ, et al. High sensitivity of BRCA1-deficient mammary tumors to the PARP inhibitor AZD2281 alone and in combination with platinum drugs. Proc Natl Acad Sci U S A. 2008; 105:17079-17084.

85. Kinders RJ, Hollingshead M, Khin S, Rubinstein L, Tomaszewski JE, Doroshow JH, Parchment RE, National Cancer Institute Phase 0 Clinical Trials T. Preclinical modeling of a phase 0 clinical trial: qualification of a pharmacodynamic assay of poly (ADP-ribose) polymerase in tumor biopsies of mouse xenografts. Clin Cancer Res. 2008; 14:6877-6885. 